\title{
Anatomia uczuć w przekładzie. Strategie tłumacza w oddawaniu warstwy emocjonalnej tekstu literackiego na przykładzie powieści Partygirl Marlene Streeruwitz
}

\author{
Joanna Bukowska \\ INSTYTUT FILOLOGII GERMAŃSKIEJ, UNIWERSYTET IM. ADAMA MICKIEWICZA \\ AL. NIEPODLEGŁOŚCI 4, 61-874 POZNAŃ \\ jbukowska@amu.edu.pl
}

\begin{abstract}
The focus of this article is an examination of translator's dilemmas related to the rendering of emotions in the translation process. he relationship between emotions and the translation process is analyzed on the example of the novel Partygirl Marlene Streeruwitz and its Polish translation by Emilia Bielicka. The study focuses on the problem of translating emotional elements that are present in the source text and sheds light on how emotions can be translated. The article provides an introduction to the author's context which is of significance in understanding the role of emotions in the source text. The study shows how the Austrian writer conceives language and uses stylistic means and writing techniques to incorporate emotions into language structures. The analytical part consists of fragments of the novel that emphasize the emotional states of the main character and is devoted to the exploration of the lexical, syntactic and stylistic features. The undertaken analysis reveals the translator's strategies and examines his decisions.
\end{abstract}


Joanna Bukowska: Anatomia uczuć w przekładzie. Emocjonalna warstwa prozy Marlene Streeruwitz na przykładzie powieści Partygirl i jej oddanie w thumaczeniu na język polski

\section{Wprowadzenie}

Poniższy artykuł ma na celu przeanalizowanie warstwy emocjonalnej twórczości prozatorskiej Marlene Streeruwitz na przykładzie powieści Partygirl ${ }^{1}$ i jej oddanie w tłumaczeniu na język polski autorstwa Emilii Bielickiej². Punktem wyjścia będzie refleksja nad tłumaczeniem literatury w kontekście emocji zawartych w tekście. Do analizy wybrana została powieść Marlene Streeruwitz pt. „Partygirl”, gdyż z uwagi na obfitość opisów silnie nacechowanych emocjonalnie stanowi ona duże wyzwanie translatorskie. Artykuł jest próbą odpowiedzi na następujące pytania - jak dużym wyzwaniem dla tłumacza jest przekład emocji widocznych w pisarstwie Streeruwitz? Jak należy oddać emocjonalną warstwę tekstu oraz repertuar środków językowych dobranych przez autorkę, które służą zaakcentowaniu obecności uczuć w tekście? W artykule uwagę poświęcono także trudnościom translacyjnym, których doświadcza najbaczniejszy z czytelników - tłumacz - w trakcie przekładu prozy Streeruwitz. W jaki sposób powinien się przygotować do procesu tłumaczenia, a następnie, jakie decyzje translatorskie musi podjąć autor przekładu biorący na swoje barki wyzwanie, polegające na oddaniu cech i wartości oryginału w języku docelowym? Kluczową część artykułu, która pozwoli odpowiedzieć na powyższe pytania, stanowi analiza obrazu twórczości Marlene Streeruwitz, jej sylwetki i przekonań, wpływających na jej prozatorską twórczość, po to, by zrozumieć stosowany przez pisarkę sposób pisarstwa, który polega na uwypukleniu w powieści Partygirl sfery uczuciowej głównej bohaterki. Dopiero gruntowne przestudiowanie światopoglądu autorki otwiera drzwi do analizy jej twórczości w ujęciu komparatystycznym.

Do analizy porównawczej wybrane zostały fragmenty powieści, w których na pierwszy plan wysuwają się stany wewnętrzne głównej bohaterki powieści. Część analityczna poświęcona została eksploracji warstwy syntaktycznej, leksykalnej oraz narracji tekstu. Spojrzenie na powieść Streeruwitz poprzez stosowany przez nią język emocji pozwoliło dotrzeć do tego, co w fundamentalny sposób konstytuuje estetykę austriackiej pisarki oraz nakreślić proces decyzyjny oraz postulaty tłumacza, pracującego z twórczością austriackiej pisarki. Trafnie proces tłumaczenia ujmuje

${ }^{1}$ Streeruwitz, M. 2002. Partygirl. Frankfurt am Main.

${ }^{2}$ Streeruwitz, M. 2004. Partygirl. przeł. Emilia Bielicka, Warszawa. 
Joanna Bukowska: Anatomia uczuć w przekładzie. Emocjonalna warstwa prozy Marlene Streeruwitz na przykładzie powieści Partygirl i jej oddanie w thumaczeniu na język polski

Lévy, pisząc: „przekład jest procesem podejmowania decyzji - serią składającą się z pewnej liczby następujących kolejno po sobie sytuacji - ruchów - jak w jakiejś grze sytuacji nakładających na tłumacza konieczność dokonania wyboru spośród (bardzo często możliwej do ścisłego określenia) liczby możliwości” (Lévy 2009: 72). Dalej Lévy wyjaśnia, że „tłumacz musi dokonać wyboru z potencjalnych znaczeń danego słowa czy motywu, z różnych koncepcji bohatera, stylu czy poglądów filozoficznych autora”, proces tłumaczenia „ma postać gry z pełną informacją”, gdzie każda decyzja wpływa na kolejną" (Lévy 2009:73).

Przeprowadzona analiza umożliwi również odpowiedź na pytanie, czy tłumaczka Emilia Bielicka rozumie kontekst autorki oraz czy konsekwentnie i świadomie przekłada na język polski strategie pisarskie zawarte w oryginale.

\section{Emocje w przekładzie}

Zdaniem Bożeny Tokarz, historyk i teoretyk literatury, która w swoim artykule pt. „Tłumacz, emocje i przekład” koncentruje się na emocjach w przekładzie, wyrażanie emocji w drugim języku jest zależne od dwóch duchów: „ducha autora oraz tłumacza”, dwóch języków oraz dwóch kultur wzajemnie na siebie oddziałujących (Tokarz 2015: 381). Tłumacz, który usytuowany jest na styku kultury wyjściowej i docelowej stanowi medium komunikacyjne między nimi (Tokarz 2015: 382). Tłumaczenie rozumiane jako efekt interakcji stwarza zarówno „sytuacje wewnątrzkontekstowe”, wynikające z obowiązku tłumacza do „naśladowania ekspresji zawartej w oryginale”, jak i „sytuacje zewnątrzkontekstowe”, które wynikają z nastawienia tłumacza do poetyki oryginału, emocji w nim wyrażonych, jak i samego autora (Tokarz 2015: 381).

Innymi słowy tłumacz powinien wykazywać empatię względem oryginału oraz jego twórcy, poznać konteksty dzieła i autora, zrozumieć więzy oryginału ze swym kontekstem, zbadać recepcję utworu w kulturze wyjściowej oraz przyjrzeć się bliżej samej sylwetce autora oryginału, by w pełni przeanalizować i odpowiednio odczytać motywy i strategie autora, a co za tym idzie dokonać ich transpozycji do innej kultury. Dopiero znając konteksty, tłumacz może dokonać procesu dekodowania tekstu i jego przeniesienia z języka źródłowego na język docelowy. 
Joanna Bukowska: Anatomia uczuć w przekładzie. Emocjonalna warstwa prozy

Marlene Streeruwitz na przykładzie powieści Partygirl i jej oddanie w thumaczeniu na język polski

\section{Emocje muszą stać się słyszalne - postulaty Marlene Streeruwitz}

Marlene Streeruwitz zaliczana jest do grona najwybitniejszych pisarek austriackich o silnie feministycznym światopoglądzie. Pisze o kobietach i dla kobiet, bardzo często komentuje podział ról we współczesnym społeczeństwie (Bukowska 2017: 217). O panującym na świecie porządku wypowiada się następująco:

„Porządkować. Uporządkowany. Porządek. Porządek. To finalny, wieczny stan. Porządek.

To wyzbycie się wszystkich czynników niepokoju. To spokój. Porządek. To martwość. Zasady czyniące życie jasnym i przewidywalnym. Przeźroczystym. Zrozumiałym” (Streeruwitz 1998:11). 3

Powyższy cytat ukazuje, w jaki sposób autorka postrzega otaczający ją świat, panujące w nim zasady i wartości, przenoszone na różne obszary życia, w tym również język. Język stanowi dla niej narzędzie do wyartykułowania pozycji i roli kobiety w społeczeństwie, która nie potrafi odnaleźć się w panującym w społeczeństwie, jej zdaniem patriarchalnym porządku językowym (Streeruwitz 1998: 22; Döbler 2004: 11). Proza Marlene Streeruwitz wykracza poza oswojone kategorie językowe, by unaocznić problem „niemej kobiety”, która nie jest w stanie wyartykułować emocji w istniejącym języku. Streeruwitz na każdym kroku łamie ogólnie przyjęte normy i zasady językowe 4 , by wpisać w jej zdaniem patriarchalne struktury doświadczenie i emocje kobiety jako matki, żony, córki (Kedves 2004: 19ff). W twórczości Streeruwitz uwidacznia się to, co podkreśla również Stefan Kaszyński, jeden z najwybitniejszych znawców literatury austriackiej w Polsce, a mianowicie fakt, że w języku literatury austriackiej uwypukla się zamiłowanie do „eksperymentu estetycznego” (Kaszyński 2009:77).

Dekonstrukcja w twórczości Streeruwitz jest więc nie tylko rodzajem „eksperymentu estetycznego”, ale przede wszystkim stała się dla pisarki środkiem artykulacji krytyki i buntu przeciwko utrwalonym w społeczeństwie porządkom. By nie utonąc w uporządkowanym i z góry narzuconym porządku symbolicznym, należy na wszelkie

\footnotetext{
3 Ordnen. Geordnet. Ordnung. Das ist Entledigung von allen Unruhefaktoren. Das ist Ruhe. Ordnung. Das ist Leblosigkeit. Sind die Regeln, die das Leben klar und überschaubar machen. Übersichtlich. Einsichtig“" (Streeruwitz 1998:11).

4 O symbolicznym porządku pisze również J. Kristeva (1974), wprowadzając kategorię tego, co somatyczne. Kategoria przejawia się we wzorcach zachowań, wzorcach językowych i podziale ról w społeczeństwie.
} 
Joanna Bukowska: Anatomia uczuć w przekładzie. Emocjonalna warstwa prozy Marlene Streeruwitz na przykładzie powieści Partygirl i jej oddanie w thumaczeniu na język polski

możliwe sposoby naginać język, by w konsekwencji posłużył on wyrażeniu emocji kobiety (Streeruwitz 1998:32). Streeruwitz dekonstruuje „poprawną i logiczną” dla świata komunikacje językowa poprzez ingerencję w strukturę zdań, przełamywanie reguł na poziomie składni, standardów poprawnościowych oraz obowiązujących norm i konwencji (Streeruwitz 1998:55). Przełamanie uporządkowanego języka, daje możliwość wyartykułowania emocji. To właśnie wyeksplikowana w tytule artykułu emocja „dochodzi do głosu” w powieści Partygirl, której warstwy leksykalna oraz syntaktyczna zostaną poddane analizie na podstawie wybranych przykładów.

\section{Emocje za szklaną taflą - perspektywa powieści Partygirl}

Partygirl to powieść Marlene Streeruwitz, która ukazała się na rynku niemieckim nakładem wydawnictwa S. Fischer Verlag w 2002 roku i była drugim dziełem prozatorskim Marlene Streeruwitz. Powieść ma strukturę segmentową, dzieli się na 13 rozdziałów, każdy z oznaczeniem miejsca i podaniem roku zdarzeń. Dzieło cechuje achronologiczne przestawienie wydarzeń, gdyż akcja rozpoczyna się w 2000 roku w Chicago, a kończy w 1955 roku w Baden. Opowiadaną wstecz historię należy odczytywać jako typową dla Marlene Streeruwitz próbę zburzenia zarówno fragmentacji istniejącego porządku, jak i linearnego trybu lektury, nie tylko na poziomie językowym, ale również na płaszczyźnie makrostruktury tekstu.

Ponadto w powieści Partygirl widoczne jest odwołanie do wzorca noweli Edgara Allana Poego pt. Zagłada Domu Usherów (The Fall of the House of Usher, 1839). Streeruwitz modyfikuje ją, nakreślając współczesną historię Austriaczki Madeline Usher oraz jej brata Rodericka, połączonych przez zakazane uczucie.5 Podstawą egzystencji bohaterki powieści Partygirl jest Madeline Ascher oraz jej głębokie przeżycia związane z życiowymi porażkami, doborem nieodpowiednich partnerów oraz jej nietypową relacją z bratem Roderickiem Ascherem. Narracja powieści utrzymywana jest w trzeciej osobie liczby pojedynczej. W powieści obecny jest narrator personalny, który relacjonuje krok po kroku świat przedstawiony, ilustruje wydarzenia oraz - stany emocjonalne głównej bohaterki. Poprzez taki sposób narracji czytelnik ma wrażenie, że narrator chowa się za postacie powieści, gdyż podczas lektury otrzymuje jedynie kompaktowy opis

\footnotetext{
5 Poe, E. 1992. Zagłada domu Usherów, przeł. Bolesław Leśmian, Warszawa.
} 
Joanna Bukowska: Anatomia uczuć w przekładzie. Emocjonalna warstwa prozy Marlene Streeruwitz na przykładzie powieści Partygirl i jej oddanie w thumaczeniu na język polski

zdarzeń, myśli i uczuć (por. Rutka 2008: 149-162, Szmorhun 2008: 163-172). Taka forma prowadzenia narracji w połączeniu z stosowaną przez Marlene Streeruwitz dekonstrukcją tekstu oraz uwypuklaniem „anomalii językowych” potęguje u czytelnika wrażenie obcości, odrealnienia, dystansu względem głównej bohaterki oraz „bycia za szybą" głównej bohaterki. Przedstawione w wybranych fragmentach uczucia i emocje czytelnik obserwuje niczym zza szyby, stając się tym samym obserwatorem akcji wydarzeń. Świat Madeline Ascher jest bardzo hermetyczny. Z uwagi na precyzyjne opisy uczuć, czytelnik daje się ponieść iluzji, że czyta dokumentację medyczną pacjenta o silnych zaburzeniach emocjonalnych i dolegliwościach somatycznych. W odbiorze czytelnika bohaterowie stają się niedostępni, a uwięzienie emocji powoduje ich wewnętrzną destabilizację, przejawiającą się $\mathrm{w}$ przełamanej makro- oraz mikrostrukturze tekstu, co wpisuje się w postulaty estetyczne Streeruwitz.

Marlene Streeruwitz manifestuje emocje w powieści Partygirl poprzez dokonanie dekonstrukcji na poziomie składni, dobitnie akcentując w tym celu technikę staccato. Taki zabieg odznacza się specyficzną poszatkowaną strukturą zdania, rytmicznością oraz powoduje powstanie anomalii językowych, które na pierwszy rzut oka wydają się chaotycznym zlepkiem słów, sprzecznym z panującym uzusem. Dopiero po zapoznaniu się ze strategią pisarską autorki staje się jasny powód jej ingerencji w strukturę języka. Dekonstrukcja stosowana przez autorkę ma na celu ukazanie, przemycenie swoich własnych przekonań o języku do materii tekstu. Dzięki technice staccato Streeruwitz dobitnie podkreśla każde słowo oraz istotę emocji głównej bohaterki. Tekst stanowi swego rodzaju psychogram, który naszpikowany jest słownictwem fachowym z zakresu medycyny. Balansowanie między językiem ogólnym a fachowym oraz zabiegi łamiące zastany porządek językowy stosowane przez Streeruwitz wymuszają konkretny odbiór tekstu, powodują, że podczas lektury czytelnikowi udzielają się emocje bohaterki.

\section{Analiza przekładu emocji na wybranych przykładach powieści Partygirl}

Poniższy cytat obrazuje scenę, podczas której Madeline Ascher nękają myśli dotyczące przemijania i związanych z nim zmian zachodzących w organizmie kobiety. 
Joanna Bukowska: Anatomia uczuć w przekładzie. Emocjonalna warstwa prozy

Marlene Streeruwitz na przykładzie powieści Partygirl i jej oddanie w thumaczeniu na język polski

Juni 1994, Berlin

War sie die Hormone gewesen. Das, was die Hormone mit ihr gemacht hatten. Getrieben von Hormonen. Und ohne Hormone. Abgewandt. Unaufmerksam. Still. Nervös. Aber nach innen. Sie lief ihren Gedanken nach. Musste ihren Gedanken nachlaufen. Uns deshalb saß sie still da. Die Gedanken im ganzen Körper. Und in fliegender Hast. Und das Dasitzen. Vollkommen still dasitzen. Fast ein Vergnügen. Und manchmal in der Wohnung in der Biberstraße. Manchmal setzte sie sich nackt vor den Spiegel. In ihrem Zimmer. Und sah nach, ob die Gedanken sich abhoben. Anstießen. Unter der Haut. Sich ausbuchteten und im Dahineilen zu sehen waren. Tiere. Maulwürfe. Wühlmäuse. Winzige Mäuse in winzigen Schlangenleibern. Gedankendurchlaufen und die Haut darüber gespannt. Manchmal ein Gefühl von Zerreißen. Ein schlechter Lampenschirm geworden wäre (Streeruwitz 2002: 83).
Czerwiec 1994, Berlin

Madeline i hormony. Co téz one $z$ nią wyprawiały. Była zdana na ich pastwę. Zaś bez nich. Stawała się duchem nieobecna. Rozkojarzona. Milcząca. Nerwowa. Skupiona na sobie. Goniąca za własnymi myślami. Z wewnętrznej konieczności. Dlatego siedziała tak długo w milczeniu. Myśli wypełniały cała jej istotę. Pędziły $\mathrm{w}$ dzikim galopie. I to siedzenie bez ruchu. Całkiem bez ruchu. Niemal z przyjemnością. Zdarzało się to w mieszkaniu na Biberstraße. Siadała czasem naga przed lustrem. W swoim pokoju. Żeby sprawdzić, czy myśli można zobaczyć. Jak się między sobą przepychają. Pod skórą. Jak tam ryją i pełzają. Niby żywe stworzenia. Krety. Nornice. Maleńkie myszki o cieniutkich wężowatych kształtach. Myśli przepływające pod napiętą skórą. Chwilami zdawało się, że ta skóra pęknie. Zły byłby z niej abażur (Streeruwitz 2004: 65).

Wśród najważniejszych części składniowych powyższego przykładu należy wymienić paralelizmy kompozycyjne. Cytat w wersji oryginalnej (War sie die Hormone gewesen) rozpoczyna się orzeczeniem, co wskazywałoby na zdanie pytające. U Streeruwitz na próżno jednak szukać na poziomie składni wykrzyknień czy znaków pytających, które porządkują tekst. W powieści widoczna jest technika staccato, która burzy porządek tekstu. Każde zdanie oddzielone jest od następnego kropką. Kropka stanowi moment, w którym zapada cisza. Zastosowanie techniki staccato sprawia, że tempo tekstu oraz jego rytm zostają spowolnione, co potęguje poczucie biernej, przeciągającej się w czasie obserwacji emocji bohaterki. W języku polskim fragment War sie die Hormone gewesen, został oddany poprzez lakoniczne sformułowanie Madeline i hormony, które nie odzwierciedla przełamania norm panujących w polskim systemie znaków, a brzmi raczej jak nagłówek prasowy. Ponadto w tekście wyjściowym 
Joanna Bukowska: Anatomia uczuć w przekładzie. Emocjonalna warstwa prozy Marlene Streeruwitz na przykładzie powieści Partygirl i jej oddanie w thumaczeniu na język polski

pierwszy plan wysuwają się powtórzenia tego samego składnika w obrębie jednego fragmentu tekstu: Sie lief ihren Gedanken nach. Musste ihren Gedanken nachlaufen., Die Gedanken im ganzen Körper., Und sah nach, ob die Gedanken sich abhoben. Kluczowym powtórzeniem jest słowo Gedanken (pol. myśli), gdyż w wersji niemieckiej intensyfikuje ono ekspresję tekstu w pierwszych dwóch pierwszych przytoczonych zdaniach. Za nimi pojawiają się kolejne powtórzenia tego samego rzeczownika. W tekście wyjściowym słowo Gedanken pojawia się wielokrotnie, co ma na celu zaakcentowanie zawiłego stanu emocjonalnego głównej bohaterki, w której burzą się emocje. W wersji polskiej tłumaczka oddała te fragmenty następująco: Goniąca za własnymi myślami. Z wewnętrznej konieczności. Myśli wypetniały cała jej istotę., Żeby sprawdzić, czy myśli można zobaczyć. W tłumaczeniu fragmentu $Z$ wewnętrznej konieczności nie pada słowo myśli, co sprawia, że fragment polski traci na dynamiczności.

Wart analizy jest także następujący fragment Manchmal ein Gefühl von Zerreißen, który został oddany w języku polskim poprzez zdanie: Chwilami zdawało się, że ta skóra pęknie. W tłumaczeniu widoczne są dwa czasowniki tj. zdawało się oraz pęknie, natomiast $\mathrm{w}$ oryginale autorka zrezygnowała $\mathrm{z}$ zastosowania czasownika $\mathrm{w}$ zdaniu. W wersji oryginalnej na pierwszy plan wysuwa się nominalizacja, natomiast po stronie polskiej widoczna jest amplifikacja objaśniająca zdawało, się, że ta skóra pęknie. Tłumaczka dokonała modyfikacji gramatycznej - przekształciła rzeczowniki w dwa czasowniki po stronie polskiej (zdawać się, pękać). Typowe dla Streeruwitz jest lakoniczne i enigmatyczne nazywanie emocji, a nie ich szczegółowe wyjaśnianie. Pomimo zamiłowania autorki do lapidarnego formułowania myśli, tłumaczka rozbudowała wersję polską o dwa czasowniki. Taka technika burzy wyeksponowaną we fragmencie źródłowym „telegraficzność” tekstu.

W odniesieniu do warstwy leksykalnej należy poddać analizie następujący fragment: Getrieben von Hormonen, który na język polski został oddany poprzez zdanie: Była zdana na ich pastwę. W wersji oryginalnej czasownik treiben (dosłownie napędzać) sprawia, że scena wydaje się czytelnikowi bardziej ożywiona. Natomiast przekład tego fragmentu nie jest już bogaty w dynamikę, gdyż nie ukazuje sposobu działania hormonów w spustoszonym przez nie ciele kobiety. Powiedzenie być zdanym na czyjąś pastwę jest nieadekwatnym tłumaczeniem zależności Madeline od jej hormonów, ponieważ nie uwypukla rytmiczności zawartej w oryginale. 
Joanna Bukowska: Anatomia uczuć w przekładzie. Emocjonalna warstwa prozy Marlene Streeruwitz na przykładzie powieści Partygirl i jej oddanie w thumaczeniu na język polski

W przytoczonym fragmencie na pierwszy plan wysuwa się ponadto motyw lustra ${ }^{6}$, który można rozumieć jako próbę zdystansowania się głównej bohaterki od targających nią emocji. Spojrzenie Madeline w lustro należy odczytywać jako spojrzenie na jej życie z innej perspektywy, bez emocji, z dystansem. Uczucie dystansu, które obrazuje przytoczony fragment udziela się również czytelnikowi powieści. Podczas obserwacji własnego ciała w lustrze Madeline przemykają w głowie różne myśli, bohaterka relacjonuje to, co widzi w lustrzanym odbiciu. W motywie lustra krystalizuje się również zastosowana przez Streeruwitz zmienna perspektywa powieści, gdyż czytelnik niejednokrotnie napotyka na opis świata przedstawionego snuty przez narratora personalnego w połączeniu ze strumieniem świadomości głównej bohaterki, oddanej poprzez mowę pozornie zależną. Motyw lustra dodatkowo intensyfikuje obecność emocji w tekście, gdyż protagonistka próbuje obserwować siebie samą w tafli lustra. Scena jawi się jako bardzo dynamiczna: Und sah nach, ob die Gedanken sich abhoben. Anstießen. Unter der Haut. Sich ausbuchteten und im Dahineilen zu sehen waren. Tiere. Maulwürfe. Wühlmäuse. Winzige Mäuse in winzigen Schlangenleibern. Gedankendurchlaufen und die Haut darüber gespannt. Fragment przełożony został na język polski w następujący sposób: Żeby sprawdzić, czy myśli można zobaczyć. Jak się między soba przepychają. Pod skórą. Jak tam ryją i pełzają. Niby żywe stworzenia. Krety. Nornice. Maleńkie myszki o cieniutkich wężowatych kształtach. Myśli przepływające pod napiętą skórą. Myśli zarysowane w powyższym przykładzie mogą stanowić metaforę targających główną bohaterką emocji - buzują w niej, przepychają się, „ryją” i „pełzają”. Tłumaczka poprawnie zrekonstruowała scenę $\mathrm{w}$ języku polskim nie tracąc $\mathrm{z}$ oczy dynamiki fragmentu wyjśsiowego.

W powieści przewijają się fragmenty opisujące obezwładniające lęki, z którymi zmagała się główna bohaterka powieści. Poniższy cytat powieści ilustruje symptomy somatyczne, jakie odczuwała główna bohaterka, podczas jednego z takich napadów lęku.

${ }^{6}$ Motyw lustra we współczesnej prozie autorek austriackich porusza również Joanna Drynda (Drynda 2012). 
Joanna Bukowska: Anatomia uczuć w przekładzie. Emocjonalna warstwa prozy

Marlene Streeruwitz na przykładzie powieści Partygirl i jej oddanie w thumaczeniu na język polski

1969, Baden

Sie bekam keine Luft. Sie wollte atmen können. Sie wollte sehen. Sie wollte niemanden so nahe. Über sich. Niemanden. Madeline richtete sich auf. Sie konnte nichts sagen. [...]

Madeline ließ sich zurückfallen. Gegen die Lehne. Sie atmete schnell. Aber sie bekam kaum Luft in sich hinein. Das Atmen kann nur bis zur Kehle. Der Hals versperrt. Die Brust versteinert. Undurchdringlich. Unerreichbar.

Madeline schlug sich gegen das Brustbein. Sie schlug sich mit der flachen Hand gegen das Brustbein. Ihr wurde heiß.

Erstickte sie. Erstickte sie auf dem altrosaverblichenen Sofa im Speisezimmer. Auf dem Sofa hatte man sitzen müssen, wenn es keine Nachspeise gegeben hatte. Oder kein Abendessen. Zur Strafe.

Und jetzt gab es auch keine Luft. Das war logisch. Madeline wunderte sich einen Augenblick, warum sie sich nicht wunderte. Wie selbstverständlich das war.

Hinter der Stirn noch der Gedanke. Kurz. Dass sie ohnmächtig wurde. Im Wegsacken die Angst dicht um das Herz. Ein Ziehen. Innen. Irgendwo tief im Kopf. Tief hinter der Kehle. Im Aufwachen. Einen Augenblick alles in Ordnung. Die Glieder locker. Der Kopf frei. Im Körper Ruhe. Süße Ruhe. Sie blieb liegen (Streeruwitz 2002: 267).
1969, Baden

Ale brakuje jej powietrza. Nie może złapać tchu. Nic nie widzi. Nie chce, żeby ktokolwiek się do niej zbliżał. Żeby się nad nią pochylał. Nie chce nikogo. Wyprostowała się. Nie mogła wykrztusić słowa. [...]

Madeline opadła na oparcie kanapy. Oddychała szybko. Powietrze nie docierało do jej płuc. Zatrzymywało się w połowie drogi. Tchawicę miała zaciśniętą. Klatkę piersiową zamurowaną. Nieprzepuszczalną. Nie do przebycia.

Madeline uderzyła się w mostek. Płaską dłonią $z$ rozmachem. Zrobiło jej się gorąco.

Czy musi się udusić. Czy się zaraz udusi, leżąc na pokrytej wyblakłym różowym obiciem kanapie w jadalnym pokoju. Na tej kanapie trzeba było siedzieć, kiedy się nie dostawało deseru. Albo kolacji. Za karę.

A teraz w dodatku brakowało człowiekowi powietrza. To było logiczne. To było przecież takie oczywiste.

Pod czołem jeszcze przelotna myśl. Że właśnie zemdlała. Zapadając się, poczuła lęk ściskający serce. Ból. W środku. Gdzieś głęboko w głowie. $\mathrm{Na}$ dnie gardła. Ledwie oprzytomniała. W jednej chwili wszystko wróciło do normy. Członki rozluźnione. Głowa wolna. W całym ciele spokój. Błogi spokój. Leżała dalej bez ruchu (Streeruwitz 2004: 206).

Fragment Hinter der Stirn noch der Gedanke. Kurz. Dass sie ohnmächtig wurde. Im Wegsacken die Angst dicht um das Herz. Ein Ziehen. Innen. Irgendwo tief im Kopf. Tief hinter der Kehle. Im Aufwachen. Einen Augenblick alles in Ordnung. stanowi dowód na to, że składnia powieści Partygirl jest poszatkowana, zdominowana przez technikę staccato. Analizując przytoczony fragment odkrywamy, że przeważają w nim rzeczowniki oraz obecny jest zaledwie jeden czasownik w parze $\mathrm{z}$ przymiotnikiem (niem. ohnmächtig werden, co w języku polskim oznacza stracić przytomoność). Należy zwrócić uwagę, że tłumaczka skumulowała dwa pierwsze fragmenty tekstu: Hinter der Stirn noch der Gedanke. Kurz, oddając je w wersji polskiej poprzez jedno zdanie: Pod czołem jeszcze przelotna myśl. Powodem takiej decyzji translatorskiej mogła być ponowna ucieczka tłumacza od zbytniej egzotyzacji tekstu. Fragment przetłumaczony dosłownie brzmiałby: Pod czołem myśl. Krótka., co czytelnik odebrałby jako element obcy, który nie mieści się w granicach norm 
Joanna Bukowska: Anatomia uczuć w przekładzie. Emocjonalna warstwa prozy Marlene Streeruwitz na przykładzie powieści Partygirl i jej oddanie w thumaczeniu na język polski

akceptowalności języka polskiego. Fragment Im Wegsacken die Angst dicht um das Herz. oddany został w języku polskim poprzez imiesłów zapadając oraz czasownik poczuć: Zapadając się, poczuła lęk ściskający serce. Dodatkowo tłumaczka opisała lęk jako ściskający serce. Tekst źródłowy nie jest tak rozbudowany i co więcej - nie wykazuje ani imiesłowów, ani czasowników ani nawet przymiotnika, ogranicza się do rzeczownika odczasownikowego das Wegsacken, pol. zanikanie, (transpozycja od czasownika wegsacken, pol. zanikać), rzeczowników die Angst (pol. strach, lęk) oraz das Herz (pol. serce), przyimka um (pol. wokót) oraz przysłówka dicht (pol. gęsto). Gdyby dosłownie przetłumaczyć zdanie na język polski, brzmiałoby ono następująco: $W$ zanikaniu strach gęsto wokół serca. Tłumaczka zdecydowała się przeformułować zdanie tak, by nie naginać norm akceptowalności języka polskiego. Należy mieć jednak na uwadze, że Streeruwitz podkreśla istotę łamania zastanego porządku językowego, czego nie ukazuje polskie tłumaczenie. Podobna strategia translatorska zastosowana została podczas przekładu fragmentu: Im Aufwachen. Einen Augenblick alles in Ordnung jako Ledwie oprzytomniała. Wjednej chwili wszystko wrócito do normy. W tekście wyjściowym ponownie widoczna jest transpozycja - das Aufwachen (od czasownika aufwachen, pol. budzić się, przytomnieć), która oddana została w wersji polskiej poprzez czasownik. Fragment Einen Augenblick alles in Ordnung został w wersji polskiej rozbudowany o wyrażenie czasownikowo-rzeczownikowe wracać do normy. Eliminując elementy obcości tłumaczka wygładziła sens zdań, a tym samym ułatwiła czytelnikowi odbiór przytoczonego fragmentu.

W prozie Streeruwitz dochodzi do mieszania stylów. Powieść Partygirl charakteryzuje styl potoczny oraz naukowy. Na pierwszy plan wysuwa się terminologia z zakresu medycyny, przy użyciu której Streeruwitz w sposób naturalistyczny opisuje wewnętrzne stany Madeline Ascher. Operowanie językiem fachowym potęguje u czytelnika wrażenie czytania „surowego” raportu medycznego, zawierającego szczegółowy opis stanu zdrowia pacjenta, którym targają emocje. Dzięki zastosowaniu terminologii z zakresu języka medycyny tekst staje się wiwisekcją kobiecych doświadczeń i emocji. Chaos i fragmentaryczność pozwalają opisać wewnętrzne stany oraz emocje głównej bohaterki. Jednym z głównych motywów powieści Partygirl jest cielesność, gdyż główna bohaterka uwypukla swoje emocje poprzez ciało. Warto zatem poddać tłumaczenie analizie właśnie pod kątem obecności terminologii medycznej. Fragment: Sie atmete schnell. Aber sie bekam kaum Luft in sich hinein. Das Atmen 
Joanna Bukowska: Anatomia uczuć w przekładzie. Emocjonalna warstwa prozy Marlene Streeruwitz na przykładzie powieści Partygirl i jej oddanie w thumaczeniu na język polski

kann nur bis zur Kehle. Der Hals versperrt. Die Brust versteinert. Undurchdringlich. Unerreichbar oddany został po stronie polskiej poprzez słowa: Oddychata szybko. Powietrze nie docierało do jej pluc. Zatrzymywało się $w$ polowie drogi. Tchawice miała zaciśnięta. Klatkę piersiową zamurowana. Nieprzepuszczalna. Nie do przebycia. Powyższy fragment można traktować jako część raportu medycznego, gdyż zarówno po stronie niemieckiej, jak i polskiej znajdziemy terminy z zakresu medycyny: tchawica, klatka piersiowa, oddychać. W tłumaczeniu widoczna jest pewna niekonsekwencja. Zdanie: Das Atmen kann bis zur Kehle, zostało oddane w języku polskim jako: Zatrzymywało się $w$ połowie drogi. Dosłowne tłumaczenie tekstu wyjściowego brzmiałoby: Oddech dochodzit tylko do gardta. Tłumaczka pominęła możliwość zastosowania terminu z języka medycyny, który wpisuje się w strategie pisarskie Streeruwitz. Przyczynę takiej decyzji translatorskiej można odczytać następująco - tłumaczka zrezygnowała ze zbytniej egzotyzacji tekstu, zrezygnowała z zachowania elementu obcości. Terminologię medyczną należy rozumieć jako metaforę stanów wewnętrznych protagonistki. W tym miejscu uwidacznia się, że autorka balansuje na granicy terminów medycznych i języka emocji, po to by przemycić w tekście swoje wyobrażenie języka, który jej zdaniem musi ulec dekonstrukcji. Wprowadzenie terminologii fachowej do powieści wywołuje $\mathrm{w}$ tekście irytacje $\mathrm{i}$ metaforyzuje stan wewnętrzny głównej bohaterki.

Podobne pominięcie można zaobserwować w następującym fragmencie: Madeline schlug sich gegen das Brustbein. Sie schlug sich mit der flachen Hand gegen das Brustbein. Ihr wurde heiß., który w języku polskim brzmi: Madeline uderzyła się $w$ mostek. Płaskq dtoniq z rozmachem. Zrobiło jej się gorqco. W wersji niemieckiej mamy do czynienia z rzeczownikiem Brustbein (pol. mostek), który występuje w przytoczonym fragmencie dwukrotnie. Po stronie polskiej nie znalazło się tłumaczenie: Ptaską dtonią z rozmachem. Zdanie powinno rozszerzyć się o zwrot: „w mostek”, by w pełni wykorzystać możliwości języka polskiego oraz zachować dekonstrukcję w formie poszatkowanych, naszpikowanych powtórzeniami zdań, która tak ważna jest dla autorki dzieła, gdyż właśnie w pracy nad językiem Streeruwitz upatruje instrument do przeforsowania jej światopoglądu.

Zastosowanie języka z zakresu medycyny determinuje również perspektywę powieści. Jak już wcześniej wspomniano z uwagi na lapidarny sposób ukazywania emocji w tekście, czytelnik ma wrażenie jakoby czytał psychogram postaci, raport 
Joanna Bukowska: Anatomia uczuć w przekładzie. Emocjonalna warstwa prozy Marlene Streeruwitz na przykładzie powieści Partygirl i jej oddanie w thumaczeniu na język polski

medyczny. Z jednej strony pozwala to utożsamić się z postacią i jej emocjami. Z drugiej jednak strony w tekście do głosu dochodzi narrator personalny, który wprowadza dystans między główną bohaterką a czytelnikiem (Szmorhun 2008: 164). Dwuznaczność perspektywy można zaobserwować na przykładzie następującego fragmentu: Madeline schlug sich gegen das Brustbein [...]. Erstickte sie. Erstickte sie auf dem altrosaverblichenen Sofa im Speisezimmer. Auf dem Sofa hatte man sitzen müssen, wenn es keine Nachspeise gegeben hatte. Oder kein Abendessen. Zur Strafe., który w wersji polskiej oddany został słowami: Madeline uderzyła się $w$ mostek [...]. Czy musi się udusić. Czy się zaraz udusi, leżąc na pokrytej wyblakłym różowym obiciem kanapie w jadalnym pokoju. Na tej kanapie trzeba było siedzieć, kiedy się nie dostawało deseru. Albo kolacji. Za karę. Powyższy fragment tekstu źródłowego oraz tłumaczenie należy odczytywać jako „mieszankę perspektyw”. W tekście swoją obecność zaznacza narrator personalny, który relacjonując stan głównej bohaterki przywołuje jej imię „Madeline”. Kolejne zdania mogą wskazywać już na myśli głównej bohaterki oddane poprzez mowę zależną: Erstickte sie. Erstickte sie auf dem altrosaverblichenen Sofa im Speisezimmer., które $w$ wersji polskiej brzmia następująco: Czy musi się udusić. Czy się zaraz udusi, leżąc na pokrytej wyblaktym różowym obiciem kanapie $w$ jadalnym pokoju. Emocjonalna strona głównej bohaterki odzwierciedla się w subiektywnej (uczucia bohaterki, o których mówi sama), ale jednocześnie obiektywnej (opowieść snuta przez narratora) narracji. Stosowana przez Streeruwitz strategia zmiennej perspektywy stanowi problem translatorski, gdyż z uwagi na obecną w tekście źródłowym pozorną mowę zależną tłumacz może mieć wątpliwości, kto jest autorem konkretnej wypowiedzi w tekście - czy są to przeżycia głównej bohaterki, czy może obserwacja tych przeżyć okiem narratora.

\section{Tłumacz w objęciach emocji oryginału - postulaty}

Transpozycja powieści Partygirl na grunt polski okazuje się być dużym wyzwaniem translatorskim nie tylko ze względu na konieczność gruntownego przestudiowania sylwetki Marlene Streeruwitz i jej kontekstów, ale również - w odniesieniu do samego procesu przekładu - z uwagi na aspekt akceptowalności oraz na dylemat związany z obraniem właściwej strategii translatorskiej, tj. egzotyzacja tekstu lub zadomowienie 
Joanna Bukowska: Anatomia uczuć w przekładzie. Emocjonalna warstwa prozy Marlene Streeruwitz na przykładzie powieści Partygirl i jej oddanie w thumaczeniu na język polski

go w kulturze docelowej. Lévy twierdzi, że proces tłumaczenia to zbiór decyzji, które na siebie wpływają, a zadaniem tłumacza jest odczytanie sensu danego tekstu między innymi w oparciu o wiedzę na temat poglądów filozoficznych samego autora (Lévy 2009: 72). Tłumacz występujący w roli pośrednika między autorem a odbiorcą, powinien innymi słowy w pierwszej kolejności poznać konteksty twórcy, by świadomie i konsekwentnie przełożyć dzieło na język kultury docelowej. Z powyższych rozważań nasuwa się następująca konkluzja: to właśnie kompetencja kulturowa, ale również dociekliwość tłumacza warunkują prawidłowe odczytanie intencji autora i transfer tekstu źródłowego do nowego układu odniesienia.

Przekład powieści Partygirl może stanowić wyzwanie translatorskie pod względem norm akceptowalności. Transfer dzieła do innej kultury trafia na opór ze strony akceptowalnego porządku języka przekładu oraz tradycji panującej $\mathrm{w}$ kulturze docelowej. Osadzając oryginał $\mathrm{w}$ nowej kulturze tłumacz może obrać strategię polegającą na unikaniu zbytniej egzotyzacji, by nie nadwyrężać norm akceptowalności języka przekładu. Z drugiej jednak strony twórczość prozatorska Marlene Streeruwitz zawiera w sobie element obcości, a sama Streeruwitz krytykuje porządek przejawiający się w języku i społeczeństwie. $Z$ tego powodu od tłumacza wymaga się kompetencji kulturowej, nie może on tracić z oczu technik stosowanych przez samą autorkę ani wygładzać jej stylu, by tekst został zaakceptowany w nowym układzie odniesienia. W obszarze działań translatorskich tłumacz powinien obrać strategie translatorskie, które uwypuklą indywidualną estetykę Streeruwitz.

W odniesieniu do twórczości Marlene Streeruwitz i jej emocjonalnej warstwy językowej Katarina Döbler przekornie pyta w jednym ze swoich artykułów (Döbler 2004: 11): Czy można czytać prozę Marlene Streeruwitz bez „instrukcji obsługi”? I odpowiada zdecydowanie przecząco. Niezbędna do właściwego odczytania jej tekstów jest znajomość kontekstów, w przeciwnym razie traci się z oczu wartości eksplikowane przez autorkę, przechodzi obojętnie wobec przemycanych w jej prozie postulatów. Proza Streeruwitz jest nośnikiem informacji, ma uświadamiać, demaskować prawdę o podziałach w społeczeństwie. Wszystkie te czynniki muszą zostać dostrzeżone przez tłumacza, w momencie, gdy tekst wyjściowy trafia na jego warsztat. Kompetencje tłumacza trafnie ujmuje Elżbieta Tabakowska:

„(...) tłumacz musi mieć zdolność odczuwania empatii w każdym możliwym sensie: jak reporter (ponieważ jak autor dobrego reportażu musi umieć „cierpieć z innymi i dzielić ich nadzieje”): jak wrażliwy 
Joanna Bukowska: Anatomia uczuć w przekładzie. Emocjonalna warstwa prozy Marlene Streeruwitz na przyktadzie powieści Partygirl i jej oddanie w thumaczeniu na język polski

odbiorca literatury (ponieważ musi umieć współodczuwać $\mathrm{z}$ bohaterami swojego autora); jak psycholog, ponieważ musi umieć wywołać w sobie uczucie empatii, co niektórzy nazywają „wrażliwością na język) i wreszcie jak dobry negocjator (ponieważ musi umieć przewidzieć reakcje swoich czytelników)" (Tabakowska, 2009). 
Joanna Bukowska: Anatomia uczuć w przekładzie. Emocjonalna warstwa prozy

Marlene Streeruwitz na przykładzie powieści Partygirl i jej oddanie w thumaczeniu

na język polski

\section{Bibliografia}

Bukowska, J. (2017). Körper schreiben - Stilmerkmale der écriture féminine in Marlene Streeruwitz ' Roman Verführungen. 3 Folge. Frauenjahre und ihre Wiedergabe in der polnischen Übersetzung, w: Beate Sommerfeld et al. (eds.): Übersetzungskritisches Handeln. Modelle und Fallstudien. Studien zur Germanistik, Skandinavistik und Übersetzungskultur. Bd. 16. Frankfurt am Main, pp. 217-227.

Döbler K. (2004). Schlussfolgerungen aus einem Selbstversuch. Darf man die Bücher von Marlene Streeruwitz ohne Beipackzettel lesen?, w: Heinz Ludwig Arnold (ed.): Text und Kritik. Zeitschrift für Literatur, München, pp. 11-18.

Drynda, J. (2012). Spiegel-Frauen: Zum Spiegelmotiv in Prosatexten zeitgenössischer österreichischer Autorinnen (Studien zur Germanistik, Skandinavistik und Übersetzungskultur). Frankfurt am Main: Peter Lang.

Kaszyński, S. (2009). Kultura i literatura austriacka w dyskursie środkowoeuropejskim, w: Studia interkulturowe 4/2009.

Kedves A. (2004). Geheimnisvoll. Vorwurfsvoll. Aber zusammenhängend. Marlene Streeruwitz Romane, Frauengeschichten, Männersprache, w: Heinz Ludwig Arnold (red.). Text und Kritik. Zeitschrift für Literatur, pp. 19-31.

Kristeva, J. (1974). La révolution du language poétique. Paris: Seuil.

Lévy, J. (2009). Przekład jako proces podejmowania decyzji, przeł. M. Adamczyk, w: P. Bukowski, M. Heydel (red.), Wspótczesne teorie przekładu. Antologia. Kraków: Znak, pp. 72-85.

Poe, E. (1992). Zagłada domu Usherów, przeł. Bolesław Leśmian. Warszawa.

Rutka, A. (2008). Zur post-patriarchalischen Konstruktion von Männlichkeit in den Dramen von Marlene Streeruwitz, w: Joanna Drynda (ed.), Ich-Konstruktionen in der zeitgenössischen österreichischen Literatur. Poznań: Ryś, pp. 149-162.

Szmorhun, A. (2008). morire in levitate. - Zu geschlechtsspezifischen Ich-Konstruktionen bei Marlene Streeruwitz, w: Joanna Drynda (ed.), Ich-Konstruktionen in der zeitgenössischen österreichischen Literatur. Poznań: Ryś, s. 163-172.

Streeruwitz M. (1998). Können. Mögen. Dürfen. Sollen. Müssen. Lassen. Frankfurter Poetikvorlesungen. Frankfurt am Main: Suhrkamp.

Streeruwitz M. (2002). Partygirl. Frankfurt am Main: Suhrkamp.

Streeruwitz M. (2004). Partygirl, przeł. Emilia Bielicka. Warszawa: Czytelnik.

Tabakowska E. (2009). Tłumaczac się z thumaczenia. Kraków: Znak.

Tokarz B. (2015). Tłumacz, emocje i przekład, w: Poznańskie Studia Slawistyczne, nr 9, pp. 381- 394 . 